\title{
PENGARUH LATIHAN NAIK TURUN TANGGATERHADAP KEMAMPUAN TENDANGAN DWI CHAGI ATLET TAEKWONDO PEMUSATAN LATIHAN DAERAH SUMATERA BARAT
}

\author{
Asep Sujana Wahyuri ${ }^{1}$, Erizal Nurmai $^{2}$, Emral $^{3}$ \\ ${ }^{1}$ Program Studi Pendidikan Jasmani Kesehatan dan Rekreasi, Fakultas Ilmu Keolahragaan, \\ Universitas Negeri Padang. Jalan Prof. Dr. Hamka Air Tawar Barat, Padang,25132, Indonesia. \\ asepsw.unp@gmail.com ${ }^{3}, \underline{\text { erizal @ fik.unp.ac.id }}{ }^{2}, \underline{\text { emral @ fik.unp.ac.id }}^{1}$
}

\begin{abstract}
Abstrak
Penelitian ini berawal dari kenyataan di Pemusatan Latihan Daerah Sumatera Barat bahwa kemampuan tendangan yang dilakukan atlet tidak sesuai dengan harapan. Melihat gejala tersebut maka dapat dirumuskan masalah dalam penelitian ini yaitu bagaimanakah pengaruh Latiha naik turun tangga terhadap kemampuan tendangan $d w i$ chagi atlet Taekwondo Pemusatan Latihan Daerah Sumatera Barat. Yang bertujuan untuk melihat Pengaruh Latihan Naik Turun Tangga Terhadap Kemampuan Tendangan Dwi Chagi Atlet Taekwondo Pemusatan Latihan Daerah Sumatera Barat

Penelitian ini merupakan penelitian eksperimen semu. Populasi dalam penelitian ini adalah atlet taekwondo Pemusatan Latihan Daerah Sumatera Barat yang berjumlah 29 orang atlet. Pengambilan sampel menggunakan teknik Total Sampling dengan sampel berjumlah 18orang atlet putra dan 11 atlet putri. Penelitian ini dilaksanakan pada 2 Mei sampai 31 Mei 2016 dengan 4 kali pertemuan, latihan diberikan dalam bentuk Naik Turun Tangga.

Hasil pengujian hipotesis dari penelitian ini diperoleh hasil untuk atlet putrat ${ }_{\text {hitung }}(4,123)>$ $t_{\text {tabel }}(2,00)$,dan atlet putri $t_{\text {hitung }}(8,117)>t_{\text {tabel }}(2,49)$, artinya penerapan latihan Naik Turun Tangga dapat meningkatkan kemampuan tendangan $d w i$ chagiatlet taekwondo Pemusatan Latihan Daerah Sumatera Barat.

Kata Kunci:Latihan naik turun tangga, Tendangan Dwi Chagi
\end{abstract}

\section{PENDAHULUAN}

Belum maksimalnya prestasi atlet ini dikarenakan banyak faktor seperti fisik,teknik, taktik dan mental. Berikut beberapa faktor fisik yang dimaksud 1. Daya tahan (endurance), 2. Kekuatan (strength), 3. Daya ledak ( explosive power), 4. Kecepatan (speed), 5. Kelenturan (flexibility), 6. Kelincahan (agility), 7. Keseimbangan (balance), 8. Koordinasi (koordination).

Adapun permasalahan yang menjadi pusat perhatian peneliti adalah dari segi fisik salah satunya daya ledak otot tungkai atlet taekwondo Pemusatan Latihan Daerah Sumatera Barat. Hal ini terbukti sering kali atlet melakukan kesalahan dalam melakukan tendangan diantaranya yaitu: tendangan yang dilakukan tidak kuat, tidak lagi akurat, tidak terkontrol dengan baik, dan kekuatan tendangan menurun. Lemahnya daya ledak otot tungkai mengakibatkan rendahnya kualitas tendangan sehingga mempengaruhi penampilan atlet pada saat melakukan tendangan dan mengakibatkan turunnya motivasi yang dimiliki atlet pada saat bertanding. Daya ledak otot tungkai ini dapat dilatih dengan bentuk latihan naik turun tangga

Jika hal ini dibiarkan, maka ditakutkan akan menimbulkan permasalahan baru dalam kemampuan tendangan atlet, sehingga prestasi maksimal yang diharapkan oleh pembina taekwondo akan sulit untuk diraih. Salah satu tendangan yang dimaksudkan adalah Tendangan Dwi Chagi. Tendangan Dwi Chagi merupakan salah satu teknik tendangan memutar kearah perut/ kepala yang dapat menjatuhkan lawan disamping penambahan nilai yang sangat tinggi. Oleh sebab itu, peneliti tertarik untuk membuktikan secara ilmiah melalui penelitian dengan judul " Pengaruh Latihan Naik Turun Tangga Terhadap Kemampuan Tendangan Dwi Chagi Atlet Taekwondo Pemusatan Latihan Daerah Sumatera Barat".

Taekwondo merupakan salah satu olahraga seni beladiri nasional Korea yang populer di dunia dan disukai banyak masyarakat dan juga sampai kepada masyarakat Indonesia. Seni beladiri ini sudah berkembang menjadi olahraga beladiri yang sangat digemari oleh semua lapisan masyarakat, dari anak-anak 
sampai orang tua, laki-laki maupun perempuan, masyarakat kota sampai masyarakat desa. Hal ini terbukti dengan banyaknya klub-klub (dojang) taekwondo yang tersebar di seluruh pelosok tanah air dengan berbagai bentuk tujuan yang diharapkan.

Dari uraian di atas dapat dilihat bahwa prestasi olahraga bela diri taekwondo Indonesia harus didukung oleh pembinaan dan pengembangan secara terencana, berjenjang dan berkelanjutan dengan dukungan ilmu pengetahuan dan teknologi keolahragaan. Di samping itu juga dibutuhkan bakat kemampuan dan potensi untuk mencapai prestasi. Sehubungan dengan ini Syafruddin (2011: 22) mengemukakan:

Ada dua faktor yang mempengaruhi dalam mencapai prestasi, faktor tersebut adalah faktor internal dan faktor eksternal. Faktor internal adalah faktor yang timbul dari dalam diri atlet taekwondo seperti kondisi fisik, teknik, taktik, mental (psikis), sedangkan faktor eksternal adalah faktor yang datang dari atas diri atlet taekwondo seperti sarana dan prasarana, pelatih, pembina, keatasga, organisasi, dana, iklim, makanan yang bergizi dan banyak lagi yang lainnya.

Sesuai dengan tuntutan olahraga beladiri taekwondo yaitu menyerang untuk menang dan mempertahankan diri supaya tidak dikalahkan, maka bagi setiap atlet taekwondo dituntut agar memiliki berbagai keterampilan, teknik dan taktik di samping kondisi yang prima. Lebih lanjut, taekwondo menuntut kreativitas teknik, keberanian dan kepercayaan diri untuk menang dalam setiap pertandingan. Menurut Kurniawan (2011:78) bahwa "seluruh kegiatan dalam bela diri taekwondo dilakukan dengan tiga komponen dasar taekwondo, yaitu; pukulan, tendangan dan tangkisan".

Berdasarkan tujuan tersebut, salah satu teknik dasar yang sangat penting untuk dikuasai yaitu teknik Tendangan. Tendangan merupakan kemampuan atlet taekwondo melakukan serangan dengan menggunakan kaki untuk pencapaian tujuan yaitu mengadakan serangan cepat, menepis tendangan lawan, memancing lawan, mengatur tempo serangan serta menjatuhkan lawan secara efektif dan efisien tanpa kehilangan keseimbangan dan kelelahan yang berarti selama pertandingan. Dengan memiliki kemampuan tendangan yang baik, maka diharapkan setiap atlet taekwondo dapat mencapai tujuan yang diinginkan
Menurut Pratiwi (2008:214) bahwa pada perkembangan taekwondo modern saat ini tendangan sudah sangat variatif seperti: a) Tendangan depan/ke arah kepala ( $A p$ Chagi/Eolgol Ap Chagi), b) Tendangan setengah melingkar/ke arah kepala Dollyeo Chagi/ Eogol Dollyeo Chagi, c) Yeop Chagi, d) Dwi Chagi, e) Naeryo Chagi/Del O Chiki danf) Dwi Hurigi. Di samping itu, Tendangan merupakan salah satu teknik dasar taekwondo yang dapat meningkatkan motivasi atlet taekwondo karena lahirnya penambahan nilai dari kemampuan Tendangan, maka semangat bertanding akan bertambah.

Menurut Dofi (2008:3) mengemukakan bahwa "Kemampuan tendangan yang baik dapat dihasilkan dari teknik yang baik, ketahanan fisik atlet, kekuatan otot tungkai, program latihan yang tepat dan penanganan yang baik dari pelatih. Jadi, dapat dikemukakan bahwa untuk mewujudkan kemampuan tendangan yang baik semua itu diduga membutuhkan bentuk latihan yang tepat dari daya ledak otot tungkai salah satu bentuk latihannya yaitu naik turun tangga terhadap kemampuan tendangan atlet taekwondo. Tujuan latihan yang jelas dan tepat dapat membantu dalam meningkatkan kemampuan tendangan atlet. Dengan demikian, perlu rancangan secara sistematis dalam pelaksanaan latihan, terutama pengaruh latihan naik turun tangga.

Bertolak dari pendapat di atas, permasalahan ini diduga terjadi pada atlet taekwondo Pemusatan Latihan Daerah Sumatera Barat. Mereka melakukan latihan empat kali seminggu, namun dalam hal pencapain prestasi dapat dikategorikan belum mencapai prestasi yang maksimal.

Mencermati peraturan pertandingan, dimana dalam satu babak pertandingan membutuhkan waktu 2 menit. Dalam hal ini seorang atlet harus dapat melancarkan serangan dengan kuat agar poin tendangan didapatkan serta mampu mempertahankan gerakan dalam rentang waktu yang lama, terutama melakukan tendangan. Agar dapat memperoleh nilai seorang atlet harus dapat melakukan serangan dengan tendangan yang kuat,cepat dam tepat, maka dalam hal ini bagi seorang atlet harus membutuhkan daya ledak yang baik. Selanjutnya, daya ledak otot tungkai yang baik diharapkan dapat memberikan poin yang tinggi untuk seorang atlet dalam melakukan tendangan. Oleh sebab itu, seorang atlet taekwondo sangat membutuhkan unsur daya 
ledak otot tungkai. Jadi, jelaslah bahwa daya ledak otot tungkai merupakan hal yang krusial dalam mencapai prestasi yang maksimal.

Berdasarkan pemantauan peneliti dari fenomena yang terjadi di lapangan dan keterangan yang diperoleh dari pelatih taekwondo diperoleh keterangan atlet taekwondo Sumatera Barat belum memperoleh prestasi yang maksimal seperti belum adanya atlet yang meraih medali emas Pekan Olahraga Nasional.

Lebih lanjut, Syafruddin (2011:142) mengemukakan bahwa:"Kemampuan mempunyai arti prestasi atau kapasitas, merupakan kemampuan aktual yang dapat diukur langsung dengan tes tertentu". Jadi, kemampuan merupakan bagaimana seseorang dapat memperoleh kualitas tindakan yang terampil. Kemampuan yang dimaksudkan dalam penelitian ini adalah kemampuan tendangan dalam seni beladiri taekwondo.

Selanjutnya, tendangan adalah sepakan atau terjangan. Menurut Pratiwi (2011:77) mengemukakan bahwa

"Secara umum serangan kaki disebut sebagai tendangan". Artinya, tendangan merupakan serangan yang dilakukan dengan kaki dan dilaksanakan dengan kuat, cepat dan akurat. Pada dasarnya, menendang memiliki arti menggunakan otot tungkai ke dalam tendangan dan melepaskannya ke tubuh lawan. Pada saat melakukan tendangan membutuhkan kekuatan dan keseimbangan yang baik untuk berdiri atau bertumpu pada satu kaki.

Tujuan dari teknik tendangan dalam seni beladiri taekwondo adalah untuk memperoleh nilai terbanyak agar dapat memenangkan pertandingan. Jadi, dapat dikemukakan bahwa kemampuan tendangan yang dimaksudkan dalam penelitian ini adalah kemampuan tendangan Dwi chagi atlet taekwondo Pelatihan Daerah Sumatera Barat. Menurut Kurniawan (2011:78) mengemukakan bahwa "tendangan $d w i$ chagi adalah tendangan memutar dengan sasaran perut/ kepala".

$$
\text { Menurut Pratiwi (2011:214) }
$$

mengemukakan bahwa: "Teknik tendangan $D w i$ chagi merupakan serangan memutar yang bernilai tinggi dan cepat serta mudah untuk menjatuhkan lawan oleh seorang atlet taekwondo dibandingkan dengan melakukan teknik pukulan (jireugi) sewaktu bertanding". Kemudian bentuk tendangan dwi chagi:

Tendangandwi chagi dapat dikatakan bagus yaitu sesuai dengan teknik yang ada dalam tendangan $d w i$ chagi yaitu mempunyai tenaga, arah sesuai dengan sasaran yang hendak dituju (perut/ kepala lawan). Dalam sistem penilaian dalam suatu pertandingan baik pertandingan gerakan tendangan $d w i$ chagi yang mendapat nilai bagus adalah tendangan yang sesuai dengan teknik, kuat dan mengenai sasaran. Selanjutnya, untuk mendapatkan tendangan $d w i$ chagi yang bagus haruslah ditunjang dengan latihan, baik itu latihan fisik maupun dengan latihan teknik dan seorang pelatih tentu sudah mengetahui dengan baik bagaimana program latihan yang hendak diberikan kepada atlet agar sasaran yang diinginkan dapat tercapai dengan baik nantinya. Sehingga melahirkan suatu prestasi yang membanggakan bagi atlet, pelatih, perguruan, daerah bahkan bangsa.

Jadi dapat disimpulkan tendangan $d w i$ chagi adalah tendangan yang dilakukan oleh kaki dengan gerakan memutar kearah perut/ kepala. Bagian kaki yang digunakan untuk menendang sasaran adalah telapak kaki dan kaki lainnya menjadi tumpuan. Kemampuan tendangan yang dimaksudkan dalam penelitian ini adalah kemampuan dwi chagi atlet taekwondo Pelatihan Daerah Sumatera Barat. Pada dasarnya, tendangan ini sangat efektif dan efisien jika digunakan dalam pertandingan. Gerakan yang memiliki unsur keseimbangan dan akurat harus ditunjang oleh daya ledak otot tungkai. Apabila tendangan $d w i$ chagi yang dilakukan atlet tidak memiliki daya ledak, maka poin tidak akan bertambah dan tidak dapat menjatukan lawan. Setelah itu posisi kuda-kuda atau kaki tumpuan tidak lagi baik mengakibatkan jarak jangkau tendangan yang dilakukan tidak tepat dan lintasan serangan sering salah karena terhalang oleh bagian tubuh lawan seperti - tangkisan dan elakan, akibatnya atlet tidak akan mendapatkan nilai. Jadi, jelas bahwa dalam pertandingan beladiri taekwondo, faktor utama yang dibutuhkan dalam kemampuan tendangan dwi chagi adalah unsur daya ledak otot tungkai.

Kekuatan kondisi fisik merupakan modal utama dalam pencapaian prestasi olahraga. Salah satu unsur kondisi fisik yang memiliki peranan penting dalam olahraga taekwondo sebagai suatu pendukung dalam melakukan tendangan dalam upaya pencapaian gerak yang sempurna adalah Daya ledak. Daya ledak atau sering disebut istilah muscular power adalah kemampuan untuk menampilkan atau 
mengeluarkan kekuatan secara eksplosif atau dengan cepat.

Menurut Rothig dalam Syafrudin (2011:72) mengatakan "Daya ledak merupakan terjemahan dari kata explosivepower atau power (bahasa inggris) dan scnelkraft (bahasa jerman). Berdasarkan kamus pengetahuan olahraga jerman, scenelkraft $=$ power yang berarti kemampuan untuk meraih suatu kekuatan setinggi mungkin dalam waktu yang singkat".

Melihat dari defenisi-defenisi diatas dapat dikemukakan bahwa Daya ledak merupakan perpaduan kombinasi antara kekuatan dan kecepatan. Kekuatan disini diartikan sebagai kemampuan atau sekelompok otot mengatasi beban, baik beban dalam arti tubuh sendiri maupun beban dalam arti benda atau alat yang digerakkan oleh tubuh. Sedangkan kecepatan menunjukkan cepat lambatnya otot berkontraksi mengatasi beban. Kombinasi keduanya itulah yang menghasilkan kecepatan gerakan secara ekplosive

Daya ledak sangat penting sekali bagi atlet taekwondo ini dikarenakan daya ledaklah yang menetukan seberapa keras seseorang dapat menendang dan seberapa jauh seseorang menjatuhkan lawan nya dalam bertanding.semuanya dalam keadaan sewaktuwaktu dapat meledak secara maksimal dalam memperoleh kekuatan secara baik dan maksimal.

Latihan adalah suatu proses berlatih yang sistematis yang dilakukan secara berulangulang dan kian hari jumlah beban latihannya kian bertambah. Agar prestasi dapat meningkat, latihan haruslah berpedoman pada teori serta prinsip latihan yang benar dan yang sudah diterima secara universal. Tanpa berpedoman pada teori serta prinsip latihan yang benar, latihan seringkali menjurus ke praktek melatih dan latihan yang tidak sistematis dan metodis sehingga peningkatan prestasipun sukar dicapai.

Dalam suatu perencanaan latihan harus tergambar dengan jelas tujuan latihan yang akan di capai, metode dan materi yang digunakan untuk mencapai tujuan tersebut serta sarana dan prasarana yang diperlukan. Sedangkan yang dimaksud dengan teratur dan sistematis adalah menunjukkan kesinambungan latihan yang dilakukan sesuai dengantahapantahapanperencanaan latihan dengan mempertimbangankan prinsip-prinsip latihan.

Sedangkan latihan menurut Rothig dalam Syafruddin (2011:21) mengatakan" Latihan adalah suatu proses pengolahan atau penerapan materi latihan seperti keterangan keterangan gerakan dalam bentuk pelaksanaan yang berulang-ulang dan melalui tuntutan yang bervariasi". Prinsip-prinsip latihan merupakan azas atau ketentuan mendasar dalam proses pembinaan dan latihan yang harus dipatuhi terutama oleh pelatih dan peserta latihan. Pemahaman tentang prinsip-prinsip latihan harus dipahami oleh pelatih dan peserta latihan. Apabila seorang pelatih dan peserta latihan tidak memahami pelaksanaan prinsip latihan maka tujuan dari pelaksanaan latihan tersebut akan sulit dicapai.

Menurut Harsono dalam Maidarman (2010:06)"Untuk mempercepat peningkatan prestasi, latihan tidak cukup hanya dilakukan secara motorik (dengan gerakan) saja. Banyak penelitian telah membuktikan bahwa latihan motorik harus dibarengi dengan metode latihan nir-motorik (tanpa gerakan). Latihan nirmotorik bisa dilakukan dengan melihat gambargambar atau film mengenai gerakan yang dilakukan. Dapat juga dengan memvisualisasi atau mencitrakan gerakan yang akan dipelajari.

Menurut Irawadi (2011:13)

mengemukakan "Program latihan adalah seperangkat rencana kegiatan latihan yang disusun sedemikian rupa sebagai pedoman dalam berlatih untuk jangka waktu tertentu dan tujuan tertentu". Dalam merancang sebuah program latihan, dibutuhkan persiapan sebaik mungkin seperti, persiapan waktu pelaksanaan yang akan di perlukan. Salah satu aspek yang perlu mendapatkan perhatian dalam penyusunan program latihan adalah tingkat kemampuan atlet saat ini.

Latihan akan meningkatkan prestasi kerja, dan peningkatan itu dipengaruhi oleh pemberian beban atau tenaga, pengaturan irama atau frekuensi, masa istirahat dan lamanya kerja. Menurut Bompa dalam Bafirman dan Apri Agus, 2008:19) "Jadi, ruang lingkup latihan harus menambah kapasitas kerja organisme dan dengan keterampilannya, melakukan hal yang sama dengan mengembangkan ciri-ciri kejiwaan yang kuat, akan mengakibatkan meningkatnya prestasi seseorang”.

Sebelum atlet melakukan latihan, terlebih dahulu atlet harus melakukan pemanasan yang bertujuan untuk meningkatkan suhu tubuh supaya terhindar dari terjadinya cidera. Selanjutnya sebelum selesai melakukan 
latihan, atlet harus melakukan pelemasan.

Berdasarkan penjelasan di atas dapat disimpulkan bahwa Latihan adalah suatu aktivitas olahraga yang dilakukan secara sistematis dalam waktu yang lama dan ditingkatkan secara progressive dan individual yang mengarah kepada ciri-ciri fungsi fisiologis dan psikologis untuk mencapai sasaran yang telah ditentukan.

\section{METODE}

Penelitian ini berupa penelitian eksperimen dengan Rancangan The One Group Pretest-postest Designyaitu untuk mengetahui seberapa besar pengaruh Latihan Naik Turun Tangga terhadap kemampuan tendangan $d w i$ chagi atlet taekwondo Pemusatan Latihan Daerah Sumatera Barat. Penelitian ini dilaksanakan tanggal 2 mei sampai 31 mei 2016. Penelitian ini dilaksanakan di Gelanggang Olahraga Haji Agus Salim Padang.

Sampel dalam penelitian ini atlet putra dan putri yang berlatih di Pemusatan Latihan Daerah Sumatera Barat. Dengan demikian jumlah sampel dalam penelitian ini adalah sebanyak 29 orang atlet putra dan putri.

\section{Pembahasan}

Berdasarkan hasil pengujian hipotesis menggunakan pendekatan statistik uji-t diperoleh harga untuk atlet putra $\mathrm{t}_{\text {hitung }}=4,123$ dan $\mathrm{t}_{\text {tabel }}(\alpha=0,05)=2,00$ dan untuk atlet putri $\mathrm{t}_{\text {hitung }}=8,117$ dan $\mathrm{t}_{\text {tabel }}(\alpha=0,05)=2,49$ yang berarti dari kedua data diatas $\mathrm{t}$ hitung $>\mathrm{t}$ tabel memberikan pengaruh yang signifikan terhadap peningkatan kemampuan tendangan $d w i$ chagi atlet taekwondo pemusatan latihan daerah Sumatera Barat. Dengan kata lain hipotesis penelitian yang diajukan secara signifikan teruji kebenarannya.Jadi metode latihan naik turun tangga merupakan salah satu bentuk latihan yang berguna untuk meningkatkan daya ledak otot tungkai yang berpengaruh terhadap kemampuan tendangan $d$ wi chagi.

Berdasarkan analisis data hasil penelitian diperoleh peningkatan yang signifikan terhadap kelompok yang diteliti. Pemberian perlakuan selama 16 kali pertemuan dengan frekuensi 4 kali seminggu memberikan pengaruh terhadap peningkatan kemampuan tendangan $d w i$ chagi atlet taekwondo Pemusatan Latihan Daerah Sumatera Barat. Latihan dalam penelitian ini intensitasnya semakin lama semakin meningkat 2 set pada sesi pertama dan terus meningkat sampai 4 set pada sesi terakhir ( sesi ke-16). Dengan rata-rata waktu pelaksanaan 30 menit, frekuensi latihan 4 kali seminggu pelaksanaan berlari dan melompat anak tangga secepat mungkin. Latihan untuk meningkatkan kemampuan daya ledak otot tungkai sangat penting. Daya ledak otot tungkai dapat ditingkatkan melalui bentuk-bentuk latihan yang merangsang otot untuk selalu berkontraksi dengan cepat baik saat memanjang (eccentric) maupun memendek (concebtric). Bentuk latihan tersebut salah satunya latihan naik turun tangga yang bertujuan menghubungkan gerakan kecepatan dan kekuatan untuk menghasilkan gerakan - gerakan daya ledak.

Untuk melakukan latihan naik turun tangga tersebut dapat diawali dengan posisi menghadap tangga kemudian berlari / melompat menaiki anak tangga kedua lengan diayun disamping badan latihan dilakukan sesuai intensitas yang telah ditentukan dalam program latihan. Usahakan agar tubuh benar-benar beristirahat setiap setnya. Latihan dalam penelitian ini mempunyai intensitas yang semakin lama semakin tinggi ( intensitas maksimal) . semakin besar kecepatan dan kekuatan yang diterima / ditahan otot saat kontraksi dalam latihan naik turun tangga maka semakin besar pengaruhnya dalam peningkatan daya ledak otot tungkai yang secara tidak langsung berpengaruh terhadap kemampuan $d w i$ chagi atlet taekwondo. Saat melakukan tendangan $d w i$ chagi atlet membutuhkan daya ledak otot tungkai yang baik dan untuk memperoleh daya ledak otot tungkai yang baik dapat dilakukan dengan latihan naik turun tangga karena melibatkan seluruh otot tungkai saat latihan dan otot tungkai yang terlibat sama saat melakukan kemampuan tendangan dwi chagi.

Untuk mengetahui seberapa besar pengaruh pendekatan Latihan Naik Turun Tangga terhadap kemampuan tendangan $d w i$ chagi atlet taekwondo Pelatihan Daerah Sumatera Barat, maka dibutuhkan data dari hasil tes kemampuan tendangan $d w i$ chagi atlet taekwondo yang dapat di ukur menggunakan Processing System Sensor (PSS). Adapun kaitannya antara satu variabel dengan variabel lainnya adalah latihan dengan naik turun tangga merupakan suatu proses latihan untuk atlet agar dapat mengerahkan seluruh kemampuan tungkainya untuk memberikan pengaruh terhadap kemampuan tendangandwi chagi secara kuat,cepat dan tepat. 
Selain latihan naik turun tangga masih banyak bentuk latihan untuk meningkatkan daya ledak otot tungkai seperti :

1) lompat ditempat dengan menggunakan skipping

2) lompat maju mundur kesamping kiri dan kanan

3) lari sprint mendaki

4) lari sprint di pasir

5) dengan weight training dan lainnya

Pembahasan penelitian dimaksudkan sebagai gambaran untuk mempermudah menarik kesimpulan penelitian. Kemampuantendangan dwi chagi merupakan salah satu teknik tendangan memutar kearah perut / kepala yang dapat menjatuhkan lawan disamping penambahan nilai yang sangat tinggi..

\section{Kesimpulan}

Hasil penelitian menunjukan bahwa Terdapatnya peningkatan secara nyata dari perlakuan yang diberikan dengan latihan naik turun tangga terhadap kemampuan tendangandwi chagi, dengan demikian peneliti menyimpulkan terdapat pengaruh latihan naik turun tangga terhadap kemampuan tendangandwi chagi atlet taekwondo pemusatan latihan daerah Sumatera Barat

\section{Daftar Pustaka}

Agus Mukholid. 2004. Pendidikan Jasmani Kelas I SMA (Kurikulum Berbasis Kompetensi 2004). Surakarta: Yudistira.

Apri Agus..2012.Olahraga Kebugaran jasmani, Padang: Sukabina Press

Arsil. 1999. Pembinaan Kondisi Fisik. Padang: Fakultas Ilmu Keolahragaan Universitas Negeri Padang

Bafirman, dan Apri Agus. 2008. Buku Ajar Pembetukan Kondiasi Fisik. Padang: UNP

Depdiknas. 2008. Kamus Besar Bahasa Indonesia. Jakarta: Balai Pustaka.

Dofi, Bellavia Ariestia. 2008. Seni Beladiri Taekwondo. Jakarta: Unit Kegiatan Mahasiswa Taekwondo LPT YAI Universitas Persada Indonesia.

Fahmy Fachrezzy.2013.Melatih Kekutan Tendangan Taekwondo.Taekwondo Indonesia News. Jakarta
Feri Kurniawan. 2011. Buku Pintar Olahraga. Jakarta: Laskar Aksara.

Harsono. 1988. Latihan Kondisi Fisik. Jakarta : KONI Pusat.

Hendri Irawadi. 1996. Pengantar Ilmu Melatih. Padang : FPOK IKIP. Padang

2011:98) Kondisi Fisik dan Pengukurannya. Padang; FIK UNP 1996. Pengantar Ilmu Melatih. Padang : FPOK IKIP. Padang

Novida R. G. Proof Reader. 1996. Otot Tubuh. Jakarta: PT. Elex Media Komputindo Jakarta.

Lia Octavia. 2009. Beladiri for Muslimah. Jakarta: Lingkar Pena Kreativa.

Pearce, Evelyn C. 2002. Anatomi dan Fisiologi untuk Paramedis. Jakarta: PT. Gramedia Pustaka Utama.

Pesurnay, Paulus. (2003) : Latihan Fisik Olahraga, Buku I, II, III. Pusat Pendidikan dan Penataran LITBANG KONI Pusat: Jakarta

Pratiwi Dewi 2008. Tendangan Pamungkas Sang AP-Bal Hurigi Indonesia. Jakarta: Pustaka Intermasa.

Said Hasan. 1999. Evaluasi Kurikulum. Jakarta: Depdikbud. Dirjen Dikti Poryek Pengembangan LPTK.

Suharsimi. 2002. Prosedur Penelitian (Edisi Revisi V). Jakarta : Rineka Cipta.

Syafruddin. 1999. Dasar-Dasar Kepelatihan Olahraga. Padang: FPOK IKIP: Padang.

2011. Ilmu Kepelatihan Olahraga. Teori dan aplikasi dalampembinaan olahraga. Padang : UNP Press.

Undang-undang Republik Indonesia Nomor 3 Tahun 2005. 2009. tentang Sistem Keolahragaan Nasional. Jakarta: Diperbanyak oleh Biro Humas dan Hukum Kementerian pemuda dan olahraga Republik Indonesia 